\title{
TINJAUAN HUKUM ISLAM TERHADAP AMPIKALE DALAM SISTEM KEWARISAN MASYARAKAT BUGIS
}

\author{
Oleh. Ira Hasnita ${ }^{1}$; Asni Zubair ${ }^{2}$ \\ IAIN Bone; IAIN Bone \\ ${ }^{1}$ Irahasnitairha02@gmail.com; ${ }^{2}$ annibintizubair@gmail.com
}

\begin{abstract}
This study discusses the position of ampikale assets in the Bugis Society inheritance system. This type of field research, with data collection techniques interviews with community leaders in the District of Cina. Also, the nature of qualitative data analysis. This study aims to determine the implementation system and legal position of ampicale property located in Cina District, Bone Regency.

This research found that the ampikale distribution system was not divided like the Islamic inheritance legal system. In the Bugis tradition, ampikale property is kept until the time of inheritance. Ampikale assets are usually owned and kept by someone who is funding or paying for the care of the testator until his death. While the Islamic inheritance legal system, the inheritance (Tirkah) was first incurred the cost of care of the testator before being designated as an inheritance (Mauruts). In the perspective of Islamic law, ampikale may be done as long as its implementation is not contrary to Islamic law.
\end{abstract}

\section{Keywords: Ampikale; Bugis Society; Inheritance.}

\begin{abstract}
Abstrak
Penelitian ini membahas tentang kedudukan harta ampikale dalam sistem kewarisan masyarakat bugis. Jenis penelitian lapangan, dengan tehnik pengumpulan data interview dengan para tokoh masyarakat di kecamatan Cina. Serta, sifat analisis data kualitatif. Penelitian ini bertujuan untuk mengetahui sistem pelaksanaan dan kedudukan hukum harta ampikale yang berlokasi di kecamatan Cina kabupaten Bone.

Penelitian ini menemukan bahwa sistem pembagian ampikale tidak dibagi seperti halnya sistem hukum kewarisan Islam. Dalam tradisi masyarakat Bugis, harta ampikale disimpan sampai pada waktu pembagian warisan. Harta ampikale lazimnya dimiliki dan disimpan oleh orang yang mengongkosi atau membiayai perawatan pewaris hingga meninggal dunia. Sedangkan sistem hukum kewarisan Islam, harta peninggalan (Tirkah) terlebih dahulu dikeluarkan biaya perawatan pewaris sebelum ditetapkan sebagai harta warisan (Mauruts). Dalam pandangan hukum Islam, ampikale boleh saja dilakukan selama dalam pelaksanaannya tersebut tidak bertentangan dengan syariat Islam.
\end{abstract}

Kata Kunci: Ampikale; Kewarisan; Masyarakat Bugis. 


\section{A. Pendahuluan}

Pengaturan hukum kewarisan di Indonesia masih bersifat pluralistis, karena sekarang ini berlaku tiga sistem hukum kewarisan, yaitu hukum waris adat, hukum waris Islam, dan hukum waris KUHPerdata. ${ }^{1}$ R. Subekti beranggapan seperti halnya dengan hukum perkawinan, begitupula hukum waris di Indonesia, masih beraneka ragam. Di samping hukum waris menurut hukum adat, berlaku hukum waris menurut agama Islam dan hukum waris menurut KUHPerdata.

Masalah harta pusaka, sering menjadi sumber sengketa dalam keluarga, terutama untuk menentukan siapa-siapa yang berhak dan yang tidak berhak mendapat warisan yang pada gilirannya bisa menimbulkan keretakan keluarga. Menurut salah satu pihak dianggap sudah adil sedang menurut pihak lain masih menganggap tidak adil. Keadilan menurut pemikiran manusia sangat subjektif. ${ }^{2}$

Tidak jarang memotivasi seseorang untuk menghalalkan berbagai cara untuk mendapatkan harta benda tersebut, termasuk di dalamnya terhadap harta peninggalan pewarisnya sendiri. Kenyataan demikian telah ada dalam sejarah umat manusia, hingga sekarang. Terjadinya kasus-kasus gugat waris di Pengadilan Agama maupun Pengadilan Negeri. ${ }^{3}$

Hukum kewarisan Islam dirumuskan sebagai "perangkat ketentuan hukum yang mengatur pembagian harta kekayaan yang dimiliki seseorang pada waktu ia meninggal dunia”. Sumber pokok hukum waris Islam adalah al-Qur'an dan hadis Nabi Saw. kemudian Qiyas (analogi) dan Ijma' (Konsensus Ulama). ${ }^{4}$

Hukum kewarisan Islam adalah hukum yang mengatur tentang perpindahan hak kepemilikan harta peninggalan (tirkah) pewaris, menentukan siapa-siapa yang berhak menjadi ahli waris dan berapa bagiannya masing-masing. ${ }^{5}$ Hukum

${ }^{1}$ Surini Ahlan Sjarif dan Nurul Elmiyah, Hukum Kewarisan Perdata Barat: Pewarisan Menurut Undang-undang, Ed. 1, Cet. 3; Jakarta: Kencana, 2005, h.1.

${ }^{2}$ Amin Husein Nasution, Hukum Kewarisan:Suatu Analisis Komparatif Pemikiran Mujtahid dan Kompilasi Hukum Islam, Ed. 1, Cet. 3; Jakarta: Rajawali Pers, 2014, h. 52. h. 281.

${ }^{3}$ Ahmad Rofiq, Hukum Perdata Islam di Indonesia, (Cet. 2; Jakarta: Rajawali Pers, 2015),

${ }^{4}$ Surini Ahlan Sjarif dan Nurul Elmiyah, Hukum Kewarisan, h.2.

${ }^{5}$ Ahmad Rofiq, Hukum Perdata Islam di Indonesia, h. $282 .$. 
Tinjauan Hukum Islam terhadap Ampikale... $\mid$ Ira; Asni

kewarisan Islam mendapat perhatian besar, karena soal warisan sering menimbulkan akibat-akibat yang tidak menguntungkan bagi keluarga yang ditinggal mati pewarisnya, naluriah manusia yang menyukai harta benda sebagaimana tersebut dalam QS. Ali Imran: 14;

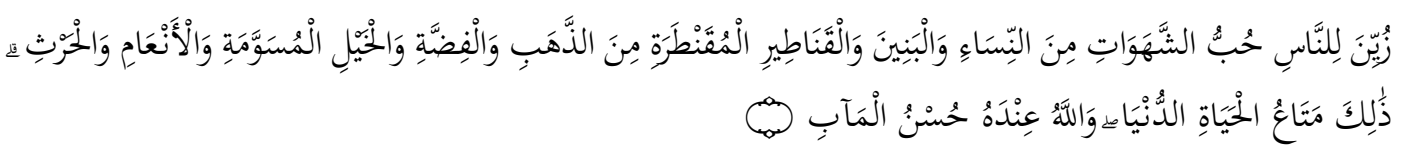

Terjemahnya: Dijadikan indah pada (pandangan) manusia kecintaan kepada apaapa yang diingini, yaitu: wanita-wanita, anak-anaknya, harta yang banyak dari jenis emas, perak, kuda pilihan, binatang-binatang ternak dan sawah ladang. Itulah kesenangan hidup di dunia, dan disisi Allahlah tempat kembali yang baik(surga). ${ }^{6}$

Hukum kewarisan Islam pada dasarnya berlaku untuk umat Islam di mana saja di dunia ini. Sungguhpun demikian, corak suatu negara Islam dan kehidupan masyarakat di negara atau daerah tersebut memberi pengaruh atas hukum kewarisan di daerah itu. Pengaruh itu adalah pengaruh terbatas yang tidak dapat melampaui garis pokok-garis pokok dari ketentuan hukum kewarisan Islam tersebut. ${ }^{7}$

Selain itu, hukum waris adat meliputi keseluruhan asas, norma dan keputusan/ketetapan hukum yang bertalian dengan proses penerusan serta pengendalian harta benda (materil) dan harta cita (nonmateril) dari generasi yang satu kepada generasi berikutnya. Hukum waris adat sangat beraneka ragam tergantung pada daerahnya. Dalam kewarisan adat ini ada yang bersifat patrilineal, matrilineal, ataupun bilateral. Hal ini menunjukkan adanya perbedaan-perbedaan daerah hukum adat yang satu dengan yang lainnya, yang berkaitan dengan sistem kekeluargaan dengan jenis serta status harta yang akan diwariskan. ${ }^{8}$

Sebagaimana diketahui bahwa setiap daerah memiliki adat tersendiri. Misalnya di kecamatan Cina kabupaten Bone terdapat adat yang dikenal sebagai ampikale. Menurut Nur Rahmah Ampikale berasal dari dua kata yaitu ampi yang

${ }^{6}$ Departemen Agama RI, Al-Qur'an dan Terjemahnya, (Jakarta: Intermasa,1993). h. 51.

${ }^{7}$ Sajuti Thalib, Hukum Kewarisan Islam di Indonesia, (Ed. 1, Cet. 8; Jakarta: Sinar Grafika, 2004, h. 1 .

${ }^{8}$ Surini Ahlan Sjarif dan Nurul Elmiyah, Hukum Kewarisan, h. 1. 
berarti penjagaan dan ale yang berarti diri-sendiri. ${ }^{9}$ Penelitian ini bertujuan untuk mengetahui dan mengungkap sistem pelaksanaan ampikale dalam kehidupan masyarakat dan kedudukan hukum ampikale perspektif hukum Islam.

\section{B. Metode Penelitian}

Penelitian ini merupakan penelitian lapangan (Field Research). Data diperoleh dari hasil wawancara dengan para tokoh masyarakat dan tokoh agama yang memahami ampikale. Lokasi penelitian ini di kecamatan Cina kabupaten Bone. Alasan peneliti memilih lokasi penelitian di Kecamatan Cina ini karena mayoritas masyarakat melakukan tradisi ampikale.

Pendekatan yang digunakan adalah sosiologis dan teologis normatif, yaitu melihat keadaan sosial sebagai nilai dalam masyarakat kemudian masalah diteliti dan dianalisis dengan metode kualitatif untuk mengulas gagasan dan memformulasikan pandangan dengan menggunakan hukum Islam sebagai takaran kedudukan hukum ampikale.

\section{Pembahasan}

Istilah "adat" berasal dari bahasa Arab, dan istilah ini telah hampir menjadi bahasa semua daerah di Indonesia. Adat juga dapat diartikan kebiasaan, sehingga secara sederhana hukum Adat atau Adat recht dapat diartikan ke dalam bahasa Indonesia menjadi hukum kebiasaan

Selain itu, A. Qodri Azizy memberikan konsepsi secara dinamis bahwa hukum Adat Indonesia ini, lebih tepat disebut "hukum kebiasaan” (customary law) atau hukum yang hidup di masyarakat (living law) ${ }^{10}$, sedangkan dalam pengertian yang statis adalah kebiasaan atau adat-istiadat bangsa Indonesia yang telah dijadikan sebuah disiplin dan dikategorikan secara baku. Demikian juga Soerjono Soekanto juga mengatakan bahwa pada hakekatnya hukum Adat merupakan hukum kebiasaan, artinya kebiasaan-kebiasaan yang mempunyai akibat hukum

\footnotetext{
${ }^{9}$ Nur Rahmah,'Tinjauan Hukum Islam Terhadap Adat Ampikale Pada Masyarakat Di Kecamatan Pammana Kabupaten Wajo", dalam http:// repositori. UIN-Alauddin. Ac. Id/991/1/Nur\%20Rahmah, 04 Juli 2018, h. 5.

${ }^{10}$ A. Qodri Azizy, Eklektisisme Hukum Nasional Kompetisi antara Hukum Islam dan Hukum Umum (Yogyakarta: Gama Media. 2002), h. 110.
} 
Tinjauan Hukum Islam terhadap Ampikale... $\mid$ Ira; Asni

(seinsollen), berbeda dengan kebiasaan-kebiaaan belaka, kebiasaan yang merupakan adat adalah perbuatan-perbuatan yang diulang-ulang dalam bentuk yang sama. $^{11}$

Hukum waris adat adalah Hukum yang memuat garis-garis ketentuan tentang sistem dan asas-asas hukum waris, tentang harta warisan, pewaris dan waris serta cara bagaimana harta warisan itu dialihkan penguasa dan pemiliknya dari pewaris kepada waris. Hukum waris adat sesungguhnya adalah hukum penerusan serta mengoperkan harta kekayaan dari sesuatu genarasi kepada keturunannya.

\section{Sistem Pelaksanaan Ampikale}

Hukum waris adat sangat beraneka ragam tergantung pada daerahnya. Dalam kewarisan adat ini ada yang bersifat patrilineal, matrilineal, ataupun parental. Hal ini menunjukkan adanya perbedaan-perbedaan daerah hukum adat yang satu dengan yang lainnya, yang berkaitan dengan sistem kekeluargaan dengan jenis serta status harta yang akan diwariskan. ${ }^{12}$

Sebagaimana diketahui bahwa setiap daerah mempunyai adat tersendiri contohnya di kecamatan Cina kabupaten Bone sendiri terdapat adat yang dikenal sebagai ampikale. Salah satu pengertian ampikale, dikemukakan oleh bapak M. Umar sebagai berikut: "Ampikale yaitu sebagai biaya perawatan bagi orang yang melaksanakan ampikale selama sakit sampai biaya perongkosannya pada saat meninggal dunia". ${ }^{13}$ Hal senada juga disampaikan oleh bapak Naharuddin, bahwa: "Ampikale yaitu harta orang tua yang disisihkan untuk dijadikan sebagai perongkosan atau keperluannya pada saat meninggal dunia". ${ }^{14}$ Hal ini juga disampaikan oleh bapak Abdul Wahab, bahwa: "to matua riolo denelo ritaneki jadi malai ceddi ampikale misalkan diaga ana'na atau maega ana'na jadi iga-iga naonroi mate atau tegai mate yenaro tujuanna ampikale yaitu untuk biaya

${ }^{11}$ Soejono Soekamto, Pengantar Hukum Adat Indonesia (Jakarta : Rajawali. 1993), h. 37.

${ }^{12}$ Surini Ahlan Sjarif dan Nurul Elmiyah, Hukum Kewarisan Perdata Barat: Pewarisan Menurut Undang-undang, h. 1.

${ }^{13}$ M. Umar, Imam Desa Awo, Wawancara di Desa Awo Kec. Cina, 13 November 2018.

${ }^{14}$ Naharuddin, Imam Desa Kawerang, Wawancara di Desa Kawerang Kec. Cina, 13 November 2018. 
pengurusannya nanti" ${ }^{15}$ Hal yang sama disampaikan oleh bapak Usman sebagai penyusun bahan pembinaan keluarga sakinah di KUA kecamatan Cina, bahwa: Ampikale yaitu harta yang dipersiapkan seseorang yang sudah usia lanjut untuk dipersiapkan menjelang hari-hari tuanya sampai meninggal dunia dan harta itu dipergunakan untuk keperluan sehari-hari sampai selesai penyelenggaraan segala biaya setelah meninggalnya nanti. ${ }^{16}$

Berdasarkan beberapa pengertian ampikale yang disampaikan oleh para tokoh masyarakat di kecamatan Cina kabupaten Bone, dapat disimpulkan bahwa ampikale adalah harta yang dicintai oleh orang tua yang disisihkan untuk dijadikan sebagai perongkosannyanya pada saat ia meninggal dunia dan apabila ampikalenya tidak digunakan akan tetrapi anaknya yang membiayai maka anaknyalah yang membiayai yang mengambil ampikale tersebut.

Ampikale pada dasarnya masih berlaku di lingkungan masyarakat Bugis Bone, ampikale memiliki cara-cara dalam pelaksanaannya, beberapa cara yang dikemukakan oleh bapak M. Umar sebagai berikut: "Siapa yang ditempati meninggal dan yang telah merawat orang tua selama hidupnya maka dialah yang berhak mendapat ampikale", Pembagian warisan beda dengan ampikale karena pada saat pembagian warisan biasanya orang tua menyimpan sebagian hartanya untuk dijadikan sebagai biaya perawatannya pada saat ia meninggal dunia dan biasanya yang mendapatkan ampikale itu anak perempuan atau anak bungsu karena yang sering ditinggali orang tua sampai meninggal lazimnya anak perempuan atau anak bungsu. ${ }^{17}$

Hal senada juga disampaikan oleh bapak Usman, bahwa pelaksanaan ampikale dibagi kepada Siapa-siapa yang merawat atau dimana dirawat sampai meninggal dan harta ampikale tidak dibelanjakan maka dialah yang merawat yang

\footnotetext{
${ }^{15}$ Abdul Wahab, Imam Kelurahan Tanete, Wawancara di Kelurahan Tanete, 23 November 2018.

${ }^{16}$ Drs. Usman, SH, staf KUA di Kec. Cina, Wawancara di KUA Kec. Cina, 22 November 2018.

${ }^{17}$ M. Umar, Imam Desa Awo, Wawancara di Desa Awo Kec. Cina, 13 November 2018.
} 
mengambil harta tersebut. ${ }^{18}$ Hal ini juga disampaikan oleh bapak H. Abdul Hamid, bahwa: Ampikale tidak dibagi karena tidak sama dengan warisan dan ampikale hampir sama dengan wasiat jadi siapa-siapa yang ditinggali meninggal maka dialah yang mengambil ampikale tersebut dan tidak menutup kemungkinan bahwa bukan anaknya yang mengambil karena bisa jadi bukan anaknnya yang merawat atau ditinggali sampai meninggal. ${ }^{19}$

Hal ini juga disampaikan oleh H. Manneng, bahwa: “Ampikale hanya dibagi apabila saat meninggalnya pewaris semua anaknya terlibat dalam hal pengongkosannya dan ampikalenya pewaris tidak dipakai dalam perongkosannya maka harta Ampikale tersebut dibagi ke semua anak yang mengongkosinya. ${ }^{20}$

Berdasarkan pemaparan para tokoh masyarakat tersebut, penulis dapat mengatakan bahwa cara pembagian ampikale yaitu pada saat pembagian warisan maka orang tua menyimpan sebagian hartanya untuk dijadikan sebagai ampikale atau jaminan pada saat ia meninggal dunia maka anaknya tidak akan takut mengenai biayanya karena sudah ada ampikale yang disiapkan oleh orang tuanya dan ampikale hanya diperuntuhkan bagi yang membiayai saat meninggal dan ampikale tidak dibagi seperti pembagian warisan.

Ampikale ini terkadang dilakukan oleh masyarakat Bugis, disebabkan orang tua tidak ingin memberatkan anaknya mengenai biaya pengurusannya nanti saat dia meninggal dunia dan biasanya ini dilakukan oleh orang yang tidak mempunyai keturunan karena jangan sampai tidak ada yang bisa mengongkosi pada saat meninggalnya.

Ampikale pada dasarnya memang sudah dilaksanakan oleh orang-orang terdahulu atau sudah turun-temurun sehingga sering dilakukan di tengah-tengah masyarakat adat Bugis. Cara itu memang sudah menjadi kebiasan masyarakat akan tetapi tidak semua masyarakat melakukan ampikale namun sampai sekarang masih banyak yang melakukan ampikale khususnya di masyarakat kecamatan Cina.

\footnotetext{
${ }^{18}$ Drs. Usman, SH, staf KUA di Kec. Cina, Wawancara di KUA Kec. Cina, 22 November 2018.

19 Abdul Hamid, Imam desa walenreng sekaligus pemangku adat di desa Walenreng, Wawancara di KUA Kec. Cina, 22 November 2018.

${ }^{20}$ H. Manneng, masyarakat di Kec.Cina, Wawancara di Desa Lompu, 23 November 2018.
} 
Seperti yang dikemukakan oleh bapak H. Abdul Hamid sebagai berikut: "Ampikale sudah menjadi kebiasaan masyarakat karena memang turun-temurun dari orang tua". ${ }^{21}$ Hal ini juga disampaikan oleh bapak M. Umar, bahwa: "Ampikale ini memang sudah menjadi kebiasaannya masyarakat pada saat ia membagi warisan orang tua selalunya menyimpan sebagian hartanya sebagai ampikalenya". ${ }^{2}$

Jadi dari beberapa pemaparan sebelumnya, peneliti dapat menyimpulkan bahwa adat ampikale ini memang sudah menjadi kebiasaan masyarakat khususnya msyarakat Bugis, karena memang telah dilakukan secara turun-temurun. Beberapa hal yang melatar belakangi sehingga masyarakat melakukan ampikale yang dikemukakan oleh bapak Abdul Wahab sebagai berikut:

"Latar belakang sehingga masyarakat melakukan ampikale yaitu yang pertama apabila seseorang tidak mempunyai keturunan dan jangan sampai tidak ada yang bisa membiayai maka dari itu orang tua melakukan ampikale untuk dirinya nanti sehingga ada yang bisa mengurusnya nanti karena sudah ada harta yang ia simpan untuk keperluannya nanti pada saat ia meninggal,yang kedua untuk menjaga-jaga karena walaupun ia mempunyai banyak anak akan tetapi jangan sampai anak yang ditinggalinya yang ditempatinya sampai meninggal tidak mampu untuk membiayai orang tuanya pada saat ia meninggal dunia dan yang ketiga orang tua tidak ingin memberatkan anaknya mengenai biayanya nanti pada saat ia meninggal jadi karena itulah orang tua menyimpan sebagian hartanya untuk dijadikan ampikale". ${ }^{23}$

Berdasarkan pelaksanaan ampikale tersebut ada beberapa kekurangan dan kelebihan dari pelaksanaannya seperti halnya yang dikemukakan oleh bapak Naharuddin: Bahwa kekurangan dari pelaksanaan Ampikale yaitu ketika Ampikale tidak dipakai pada saat meninggalnya maka hanya anak yang mengongkosinya yang mengambilnya walaupun mempunyai beberapa anak sedangkan kelebihan dari pelaksanaan Ampikale yaitu ahli waris tidak mencemaskan lagi masalah perongkosan si pewaris karena sudah ada harta yang disimpan untuk perongkosannya. $^{24}$

${ }^{21}$ Abdul Hamid, Imam Desa Walenreng sekaligus pemangku adat di desa Walenreng, Wawancara di KUA Kec. Cina, 22 November 2018.

${ }^{22}$ M. Umar, Imam Desa Awo, Wawancara di Desa Awo Kec. Cina, 13 November 2018.

${ }^{23}$ Abdul Wahab, Imam Kelurahan Tanete, Wawancara di Kelurahan Tanete, 23 November 2018.

${ }^{24}$ Naharuddin, Imam Desa Kawerang, Wawancara di Desa Kawerang Kec. Cina, 13 November 2018. 
Hal senada yang disampaikan oleh bapak M. Umar, bahwa: Kelebihan dari pelaksanaan Ampikale yaitu menutupi kehidupannya termasuk pemeliharaannya dan perongkosannya pada saat meninggal dan menurut bapak M. Umar bahwa tidak mempunyai kekurangan karena ini sudah nyata bahwa siapa yang mengongkosi maka dialah yang mengambil. ${ }^{25}$

Hal ini juga disampaikan oleh bapak H. Abdul Hamid, bahwa: Kelebihan dalam pelaksanaan Ampikale yaitu jelas ada yang dipakai atau digunakan dalam perongkosannya pada saat meninggalnya dan kekurangannya yaitu tidak dapat diambil oleh anak yang lainnya tapi hanya diambil oleh anak yang mengongkosi. ${ }^{26}$

Hal ini juga disampaikan oleh bapak Abdul Wahab, bahwa: "Kelebihan dari Ampikale yaitu anak yang ditempati meninggal tidak merasa terbebani walaupun sebenarnnya anak tidak pernah merasa terbebani karena memang hartanya memang orang tua tapi jangan sampai anak yang ditinggali tidak mampu (tau kasiasi), dan kekurangannya sebenarnya ada ketidakadilan. ${ }^{27}$

Jadi terkait dengan pemaparan para tokoh di atas maka peneliti dapat menyimpulkan bahwa kekurangan dari pelaksanaan Ampikale yaitu hanya anak yang merawatnya yang dapat mengambilnya walaupun mempunyai beberapa anak dan sedangkan kelebihannya yaitu sudah jelas bahwa ada yang dapat dijadikan perongkosannya pada saat meninggalnya sehingga tidak khawatir lagi dengan masalah biaya perawatannya nanti pada saat meninggalnya dan juga tidak membebani bagi anak yang ditinggalinya.

Menurut bapak Abdul Wahab, bahwa: "Biasanya yang dijadikan Ampikale adalah barang-barang yang memiliki nilai atau berharga sekali, maksudnnya berharga bahwa apabila dia membutuhkan biaya, harta itu bisa dilepaskan karena terkadang ada harta yang banyak/ tanah yang luas, tetapi butuh dipindah-tangankan,

${ }^{25}$ M. Umar, Imam Desa Awo, Wawancara di Desa Awo Kec. Cina, 13 November 2018.

${ }^{26}$ Abdul Hamid, Imam desa walenreng sekaligus pemangku adat di desa Walenreng, Wawancara di KUA Kec. Cina, 22 November 2018.

${ }^{27}$ Abdul Wahab, Imam Kelurahan Tanete, Wawancara di Kelurahan Tanete, 23 November 2018. 
terkadang ada kendala harganya rendah dan biasanya Ampikale itu spesial dan biasanya berupa emas karena pada saat dibutuhkan bisa dijual. ${ }^{28}$

\section{Pandangan Hukum Islam terhadap Kedudukan Ampikale dalam Sistem Kewarisan Masyarakat Bugis}

Hukum Islam adalah titah Allah Swt. yang berkaitan dengan aktivitas para mukallaf, baik berbentuk perintah (suruhan dan larangan), pilihan, maupun ketetapan. Hukum Islam tersebut digali dari dalil-dalilnya yang terperinci, yaitu alQur'an, sunnah, dan lain-lain yang diratifikasikan kepada kedua sumber asasi tersebut. $^{29}$

Bagi setiap pribadi muslim adalah kewajiban baginya untuk melaksanakan kaidah-kaidah atau peraturan- peraturan hukum Islam yang ditunjuk oleh peraturanperaturan yang jelas (nash-nash yang sharih). Selama peraturan tersebut ditunjukkan oleh peraturan atau ketentuan lain yang menyebutkan tidak wajibannya. Setiap ketentuan hukum agama Islam wajib dilaksanakan selama tidak ada ketentuan lain (yang datang kemudian sesudah ketentuan terdahulu) yang menyatakan ketentuan terdahulu tidak wajib. ${ }^{30}$

Demikiam pula halnya dengan hukum faraidh, tidak ada satu ketentuan pun (nash) yang menyatakan bahwa membagi harta warisan menurut ketentuan faraidh itu tidak wajib. Bahkan sebaliknya di dalam QS. Al-Nisa' ayat 13 dan 14 Allah Swt. menetapkan:

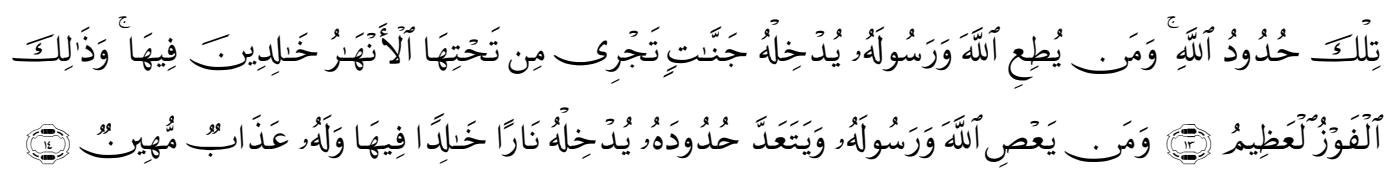

Terjemahnya: (Hukum-hukum tersebut) itu adalah ketentuan dari Allah. Barangsiapa taat kepada Allah dan Rasu-Nya, niscaya Allah memasukkanya ke dalam surga yang mengalir di dalamnya sungaisungai, sedang mereka kekal di dalamnya, dan itulah kemenangan yang besar. Dan barang siapa mendurhakai Allah dan Rasul-Nya dan melanggar ketentuan-ketentuan-Nya, niscaya Allah memasukkannya

\footnotetext{
${ }^{28}$ Abdul Wahab, Imam Kelurahan Tanete, Wawancara di Kelurahan Tanete, 23 November 2018.

${ }^{29}$ Abuddin Nata, Masail al-Fiqhiyah (Cet. I; Jakarta: Kencana, 2003), h. 5.

${ }^{30}$ Suhrawardi K. Lubis dan komis simanjuntak, hukum waris Islam, ( Ed. 2, Cet. 2; Jakarta: Sinar grafika, 2008) h. 3
} 
ke dalam api neraka sedang ia kekal di dalamnya dan baginya siksa yang mengerikan. ${ }^{31}$

Berdasarkan ketentuan kedua ayat di atas jelas menunjukkan perintah dari Allah Swt. agar kaum muslimin dalam melaksanakan pembagian harta warian mestilah berdasarkan ketentuan al-Qur'an. Dan dalam hal ini Rasulullah Saw. lebih mempertegas lagi dalam sabdanya yang diriwayatkan oleh Muslim dan Abu Dawud: bagilah harta pusaka antara ahli-ahli waris menurut kitabullah /Alqur'an. ${ }^{32}$

Namun demikian, ada sebagian pendapat yang mengemukakan bahwa pembagian harta warisan boleh tidak dilaksanakan sebagaimana ketentuan pembagian yang terdapat dalam al-Qur'an yang mana pembagiannya dapat dilaksanakan dengan jalan musyawarah di antara keluarga. Pendapat di atas sebenarnya didasarkan kepada pemahaman tentang sifat-sifat hukum, yang terdiri dari hukum yang memaksa dan hukum yang mengatur.

Disebut sebagai hukum yang memaksa apabila ketentuan hukum yang ada tidak dapat dikesampingkan, maksudnya tidak bisa tidak, perintah atau larangan hukum tersebut harus diperbuat (di dalam hukum, berbuat dapat berarti berbuat sesuatu dan dapat pula tidak berbuat sesuatu) dan seandainya tidak diperbuat maka dapat dikategorikan sebagai perbuatan melanggar hukum.

Adapun hukum yang mengatur, yaitu teks hukum yang ada dapat dikesampingkan (tidak dipedomani) seandainya para pihak berkeinginan lain (sesuai kesepakatan atau musyawarah di antara mereka), dan kalaupun tidak dilaksanakan ketentuan hukum yang ada, perbuatan tersebut tidak dikategorikan sebagai perbuatan melanggar hukum, sebab sifatnya hanya mengatur.

Bagi yang berpendapat bahwa pembagian harta warisan itu boleh menyimpang dari ketentuan al-Qur'an dan hadis, disebabkan menurut pendapat mereka ketentuan pembagian harta warisan (hukum waris) yang ada dalam teks alQur'an dan hadis tersebut bersifat sebagai "hukum yang mengatur", dan oleh

\footnotetext{
${ }^{31}$ Departemen Agama RI, Al-Qur'an dan Terjemahnya.h.118

${ }^{32}$ Abi Al- Abbas Syihabuddin Ahmad bin Muhammad al-Qasthalani , Irsyad as-sari Lisyarhi sahih al-Bukhari, (Libanon: Dar al-Fikr, t.t), h. 54, H.R. Muslim dan Abu Dawud.
} 
karena itu dapat tidak dipedomani/ dapat dikesampingkan apabila para ahli waris menghendaki lain. ${ }^{33}$

Namun demikian menurut hemat penulis, bahwa ketentuan-ketentuan pembagian harta warisan yang terdapat dalam al-Quran dan hadis adalah ketentuan hukum yang bersifat memaksa, dan karenanya wajib pulalah bagi setiap pribadi muslim untuk melaksanakannya. Apabila pembagian harta warisan di luar ketentuan tersebut, maka perbuatan itu sudah dapat dikategorikan sebagai perbuatan melanggar hukum. Adapun yang melatarbelakangi pendapat ini (wajibnya melaksanakna ketentuan pembagian harta warisan sesuai petunjuk alQuran dan hadis) didasarkan ketentuan QS. al-Nisa' ayat 13 dan 14 dan hadis rasulullah sebagaimana dikemukakan di atas, juga didasari ketentuan yang ada dalam QS. al-Nisa' ayat 29:

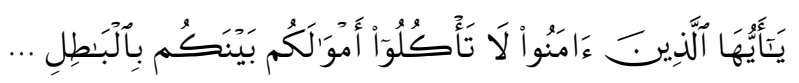

Terjemahnya: Hai orang-orang yang beriman janganlah kamu saling memakan harta sesamamu dengan jalan yang bathil. ${ }^{34}$

Berbicara tentang biaya perawatan, hibah, wasiat, dan utang pewaris sebenarnya bukan termasuk dalam lingkup hukum waris, akan teatapi bila seseorang meninggal dunia, meninggalakan harta dan ahli waris, maka tidaklah mutlak seluruh harta yang ditinggalkan oleh si pewaris tersebut menjadi hak ahli waris, sebab di dalam harta peninggalan si pewaris tersebut menjadi hak ahli waris, sebab di dalam harta peninggalan si pewaris tersebut masih ada hak-hak lain yang harus dikeluarkan terlebih dahulu sebelum harta tersebut dibagikan ke ahli waris. ${ }^{35}$

Apabila dianalisis ketentuan hukum yang ada, terdapat 4 (empat) hal yang harus diperhatikan (dikeluarkan dari harta peninggalan tersebut) sebelum dibagikan, yaitu:

a. Biaya-biaya perawatan pewaris.

${ }^{33}$ Suhrawardi K. Lubis dan komis simanjuntak, hukum waris Islam, ( Ed. 2, Cet. 2; Jakarta: Sinar grafika, 2008) h. 4.

${ }^{34}$ Departemen Agama RI, Al-Qur'an dan Terjemahnya. H. 122.

${ }^{35}$ Suhrawardi K. Lubis dan Komis Simanjuntak, Hukum Waris Islam, ( Ed. 2, Cet. 2; Jakarta: Sinar Grafika, 2008) h. 42. 
Tinjauan Hukum Islam terhadap Ampikale... $\quad$ Ira; Asni

Adapun yang dimaksud biaya-biaya perawatan si pewaris adalah biayabiaya yang dikeluarkan untuk keperluan si mayit mulai dari saat meninggalnya sampai dikuburnya ( biaya pelaksanaan fardhu kifayah). Para ahli hukum Islam sependapat bahwa biaya yang diperlukan untuk hal tersebut dikeluarkan dari harta peninggalannya menurut ukuran yang wajar. ${ }^{36}$

b. Hibah pewaris.

Kata hibah berasal dari bahasa Arab yang secara etimologo berarti melewatkan atau menyalurka, dengan demikian berarti telah disalurkan dari tangan orang yang memberi kepada tangan orang yang diberi. Dengan demikian, apabila penghibaan telah dilakukan semasda hidupnya (si mati) dan pada ketika itu belum sempat dilakukan penyerahan barang, maka sebelum harta dibagikan kepada ahli waris, terlebih dahulu harus dikeluarkan hibah tersebut. ${ }^{37}$

c. Wasiat.

Kalau diperhatikan dari segi asal kata, perkataan wasiat berasal dari bahasa arab, yaitu kata wașsaitu asy-syaira, ûshî artinya aushaituhu yang dalam bahasa Indonesianya berarti "aku menyampaikan sesuatu". Menurut ketentuan hukum Islam, bahwa bagi seseorang yang merasa telah dekat ajalnnya dan ia meninggalkan harta yang cukup (apalagi banyak) maka diwajibkan kepadanya untuk membuat wasiat bagi kedua orang tuanya (demikian juga baginkerabat yang lainnya), terutama sekali apabila ia telah pula dapat memperkirakan bahwa harta mereka (kedua orang tuanya dan kerabat lainnya) tidak cukup untuk keperluan mereka.

Persoalan wasiat ini apabila dihubungkan dengan persoalan pembagian harta warisan, maka haruslah terlebih dahulu dikeluarkan apa-apa yang menjadi wasiat dari si meninggal, barulah kemudian (setelah dikeluarkan wasiat) harta tersebut dibagikan kepada ahli waris. ${ }^{38}$

d. Utang pewaris.

${ }^{36}$ Suhrawardi K. Lubis dan komis simanjuntak, hukum waris Islam, ( Ed. 2, Cet. 2; Jakarta: Sinar grafika, 2008) h. 42.

${ }^{37}$ Suhrawardi K. Lubis dan komis simanjuntak, hukum waris Islam, ( Ed. 2, Cet. 2; Jakarta: Sinar grafika, 2008) h. 43. 
Utang adalah tanggungan yang harus diadakan pelunasannya dalam suatu waktu tertentu. Kewajiban pelunasan utang timbul sebagai dari prestasi (imlan) yang telah diterima oleh si berutang. Apabila seseorang meninggalkan utang kepada seseorang lain, maka seharusnyalah utang tersebut dibayar/dilunasi terlebih dahulu (dari harta peninggalan si mayit) sebelum harta peninggalan tersebut dibagikan kepada ahli warisnya. ${ }^{39}$

Selain hukum waris Islam, berlaku pula hukum waris adat, yang meliputi keseluruhan asas, norma dan keputusan/ketetapan hukum yang bertalian dengan proses penerusan serta pengendalian harta benda (materil) dan harta cita (nonmateril) dari generasi yang satu kepada generasi berikutnya. Hukum waris adat sangat beraneka ragam tergantung pada daerahnya. Dalam kewarisan adat ini ada yang bersifat patrilineal, matrilineal, atau parental. Hal ini menunjukkan adanya perbedaan-perbedaan daerah hukum adat yang satu dengan yang lainnya, yang berkaitan dengan sistem kekeluargaan dengan jenis serta status harta yang akan diwariskan. ${ }^{40}$

Sedangkan dalam kewarisan adat Bugis, dikenal dengan ampikale yang merupakan adat yang telah ada di lingkungan masyarakat Bugis, yang merupakan kebiasaan sebagian masyarakat bugis sebelum pembagian warisan dilakukan. Beberapa pendapat yang dikemukakan oleh beberapa tokoh di atas, penulis dapat meninjau dengan hukum Islam mengenai kedudukan ampikale dalam sistem kewarisan masyarakat bugis.

Ampikale tidak termasuk warisan karena ampikale disimpan pada saat ingin membagi warisan akan tetapi ampikale hampir sama dengan wasiat dan ampikale merupakan adat yang sejak dulu telah dilakukan oleh orang-orang terdahulu. Ampikale boleh dilakukan asalkan tidak bertentangan dengan syariat Islam, namun dilihat dari pelaksanaan ampikale ada sedikit hal yang berbeda dengan pembagian warisan dalam hukum Islam karena di dalam hukum Islam sebelum pembagian

${ }^{39}$ Suhrawardi K. Lubis dan komis simanjuntak, hukum waris Islam, ( Ed. 2, Cet. 2; Jakarta: Sinar grafika, 2008) h. 44-48.

${ }^{40}$ Surini Ahlan Sjarif dan Nurul Elmiyah, Hukum Kewarisan Perdata Barat: Pewarisan Menurut Undang-undang, h. 1. 
warisan dilakukan, dikeluarkan lebih dahulu biaya-biaya perawatan pewaris, hibah pewaris, wasiat pewaris dan utang pewaris sedangkan pembagian warisan dalam masyarakat bugis, si pewaris menyimpan sebahagian hartanya untuk dijadikan sebagai ampikale si pewaris pada saat pembagian warisan. Maka dapat dikatakan bahwa ampikale menurut Islam boleh dilakukan selama dalam pelaksanaannya tersebut tidak bertentangan dengan syariat Islam. jadi, ampikale tidak termasuk warisan karena ampikale disimpan pada saat ingin membagi warisan akan tetapi ampikale hampir sama dengan wasiat dan ampikale merupakan adat yang sejak dulu telah dilakukan oleh orang-orang terdahulu. Karena dalam Islam diajarkan bahwa Islam memuliakan adat yang tidak bertentangan dengan syariatnya, sehingga dalam Islam ampikale boleh saja.

\section{Penutup}

Berdasarkan pokok masalah dan pembahasan hasil penelitian ini, maka dirumuskan kesimpulan sebagai berikut:

a. Adapun sistem pelaksanaan ampikale tidak seperti halnya dengan pembagian warisan karena ampikale tidak dibagi seperti warisan akan tetapi disimpan pada saat pembagian warisan untuk dijadikan sebagai perongkosannya pada saat seseorang meninggal dunia agar tidak membebani anaknya.

b. Kedudukan ampikale dalam sistem kewarisan masyarakat Bugis tidak termasuk warisan karena ampikale tidak dibagi seperti warisan akan tetapi disimpan sebagai perongkosan. Sedang, di dalam hukum Islam dikeluarkan lebih dahulu biaya-biaya perawatan pewaris, wasiat, dan hutangnya, baru setelah itu warisan dibagi. Kendati demkian, ampikale tidak bertentangan dengan syariat Islam dan tradisi adat pun tetap terjaga. Karena dalam Islam diajarkan bahwa Islam memuliakan adat yang tidak bertentangan dengan syariatnya. 


\section{DAFTAR PUSTAKA}

Al-Quran Al-Karim, Al-quran dan Terjemahnya, Jakarta: Intermasa, 1993

Abdullah K, Tahapan dan Langkah-langkah dalam Penelitian, Cet. 1; Watampone: Lukman Al Hakim Press, 2013

Abdurahman, Maman, dkk, Panduan Praktis Memahami Penelitian, Cet, 1; Bandung: Cv Pustasaka Setia, 2011

Ali, Zainuddin, Pelaksanaan Hukum Waris di Indonesia, Jakarta: Sinar Grafika,2008

Arikunto, Suharsimi, Prosedur Penelitian Suatu Pendekatan Praktek, Cet. XII; Jakarta: PT Rineka Cipta, 2002

Azizy, A.Qodri, Eklektisisme Hukum Nasional Kompetisi antara Hukum Islam dan Hukum Umum, Yogyakarta: Gama Media. 2002

Bungin, Burhan, Metode Penelitian Kualitatif, Cet. 8; Jakarta: Raja Grafindo, 2011

Departemen Pendidikan Nasional, Kamus Besar Baasa Indonesia, Cet, II; Jakarta: BalaiPustaka, 2002

Departemen Agama RI, Al-Qur'an dan Terjemahnya, Jakarta: Intermasa,1993

Ghony, M. Djunaidi dan Fauzan Almanshur, Metodologi Penelitian Kualitatif, [t.Ed], Cet, 3; Jogjakarta: ArRuzz Media, 2016

Haslindah, /Skripsi"Kewarisan Anak Dari Hasil Perkawinan Beda Agama Menurut KUH Perdata Dan Kompilasi Hukum Islam", Watampone, 2017

Hasan, Muhammad Tholchah, dkk. Metode Penelitian Kualitatif Tinjauan Teoretis dan Praktis, Cet. 3; Surabaya: Visipress Media, 2009

K. Suhrawardi Lubis, dan komis simanjuntak, Hukum Waris Islam,Ed. 2, Cet. 2; Jakarta: Sinar grafika, 2008

Martono, Nanang, Metode Penelitian Sosial, Cet. I; Depok: PT Raja Grafindo Persada, 2015

Muhubbin, Moh dan Abdul Wahid, Hukum Kewarisan Islam Sebagai Pembaruan Hukum Positif di Indonesia, Ed. 1, Cet. 2; Jakarta: Sinar Grafika, 2011

Narpa, Cheryanti Imma,"kedudukan anak perempuan sebagai ahli waris menurut hukum waris masyarakat patrilineal dalam suku sentani duistrik ebungfau kabupaten jayapura" dalam http:// core. Ac. Uk, 07 juli 2018

Nasution, Amin Husein, Hukum Kewarisan: Suatu Analisis Komparatif Pemikiran Mujtahid dan Kompilasi Hukum Islam, Ed. 1, Cet. 3; Jakarta: Rajawali Pers, 2014

Nasution, Muhammad Syukri Albani, Hukum Dalam Pendekatan Filsafat, Cet, 1; Jakarta: Kencana, 2016

Nata, Abuddin, Masail al-Fiqhiyah Cet. I; Jakarta: Kencana, 2003 
Tinjauan Hukum Islam terhadap Ampikale... $\quad$ Ira; Asni

Prastowo, Andi, Memahami Metode Penelitian Suatu Tinjauan Teoritis Dan Praktis, [t.Ed], Cet, 2; Jogjakarta: ArRuzz Media, 2013

Rahmah, Nur,'Tinjauan Hukum Islam Terhadap Adat Ampikale Pada Masyarakat Di Kecamatan Pammana Kabupaten Wajo", dalam http:// repositori. UinAlauddin. Ac. Id/991/1/Nur\%20Rahmah, 04 juli 2018

Rofiq, Ahmad, Hukum Perdata Islam di Indonesia, Cet. 2; Jakarta: Rajawali Pers, 2015

Shidiq, M. Ali Ja'far,"kedudukan al-shulhu dalam kewarisan menurut fiqh dan Hukum Islam di Indonesia", http: //repository. uinjkt. ac. id/dspacel bitstream/123456789/18932/1/M. \%20ALI\%20JA\%27FAR\%20 SHIDI20 juli 2018

Simanjuntak, Hukum Perdata Indonesia,Ed. 1, Cet. 1; Jakarta: Kencana, 2005

Sjarif, Surini Ahlan dan Nurul Elmiyah, Hukum Kewarisan Perdata Barat: Pewarisan Menurut Undang-undang, Ed. 1, Cet. 3; Jakarta: Kencana,2005

Soekanto, Soerjono, Pengantar Penelitian Hukum Cet. III; Jakarta: UI-Press, 1986 -, Pengantar Hukum Adat Indonesia, Jakarta :Rajawali. 1993

Tamasari, Desi, " Pendekatan Hukum Adat Dalam Menyelesaikan Konflik Masyarakat Pada Daerah Otonom", kriminologi Indonesia Vol. 2 No. I Januari 2002.

Thalib, Sajuti, Hukum Kewarisan Islam di Indonesia, Ed. 1, Cet. 8; Jakarta: Sinar Grafika, 2004.

Wicaksono,F. Satriyo, Hukum Waris Cara Mudah dan Tepat Membagi Harta Warisan, Jakarta :Visimedia, 2011.

Widoyoko, S. Eko Putro, Teknik Penyusunan Instrumen, Cet. 1; Yokyakarta: Pustaka Pelajar, 2012. 